\title{
Chinatown Black Tigers: Black Masculinity and Chinese Heroism in Frank Chin's Gunga Din Highway
}

\section{Crystal S. Anderson Ohio University}

Images of ominous villains and asexual heroes in literature and mainstream American culture tend to relegate Asian American men to limited expressions of masculinity. These emasculating images deny Asian American men elements of traditional masculinity, including agency and strength. Many recognize the efforts of Frank Chin, a Chinese American novelist, to confront, expose, and revise such images by relying on a tradition of Chinese heroism. In Gunga Din Highway (1994), however, Chin creates an Asian American masculinity based on elements of both the Chinese heroic tradition and a distinct brand of African American masculinity manifested in the work of Ishmael Reed, an African American novelist and essayist known for his outspoken style. 1 Rather than transforming traditional masculinity to include Asian American manhood, Chin's images of men represent an appropriation of elements from two ethnic sources that Chin uses to underscore those of Asian Americans. While deconstructing the reductive images advocated by the dominant culture, Chin critiques the very black masculinity he adopts. Ultimately he fails to envision modes of masculinity not based on dominance, yet Chin's approach also can be read as the ultimate expression of Asian American individualism. 


\section{Ethnic Studies Review Volume 26: 1}

Frank Chin is no stranger to the world of Asian American literature and controversial topics regarding race and ethnicity. In works like Year of the Dragon (1981) and Donald Duk (1991) Chin explores the negative ramifications of pressures on Asian Americans to assimilate into the mainstream culture. Yet his work increasingly explores the interaction between African American and Asian American cultures. Chickencoop Chinaman (1981) tells the story of two Asian American men who admire an African American boxer and seek out his father as a part of their documentary film, while Gunga Din Highway has as a motif the intersections between Asian American and black masculinity.

In general the interplay between black and Chinese/Chinese American cultural elements in Chin's work have not been explored in depth. While scholars of Chinese American literature often attribute such characteristics as Chin's caustic style in addressing Chinese American concerns to his affinity for African American rhetoric, they stop short of satisfactory analyses. An example of this is Sau-lin Cynthia Wong who describes Chin's dramatic work as "inspired by the heroics of the Black Power movement," but does not elaborate further. ${ }^{2}$

Some forms of multicultural literary criticism also fail to provide adequate tools to investigate the cultural hybridity in Chin's work. Christopher Newfield and Avery F. Gordon assert that a particular brand of multiculturalism de-emphasizes difference:

The culturalism of multiculturalism threatens to shift attention from racialization to culture and in doing so to treat racialized groups as one of many diverse and interesting cultures. ... Given existing racial inequities and the continuing segregation of most social institutions, the reduction of all racial groups to a nonexistent level playing field poses serious problems. ${ }^{3}$

Instead of focusing on the complex ways distinct ethnic groups interact, certain brands of multiculturalism lump their histories and cultures under the heading of "Other." Such a move obscures the bicultural dynamic in Chin's work that depends on acknowledging the differences in black and Asian American expressions of masculinity. His work demands to be read with 


\section{Anderson-Chinatown Black Tigers}

critical strategies designed to hone in on the way those cultures interact and reveal the way Chin mines the African American tradition. Laurie Grobman argues that "rather than choosing one method of interpretation over another, this approach recognizes the complexity of an ethnic writer's positioning within a wide range of cultures and subcultures." 4 Chin's use of both Chinese heroism and African American masculinity demonstrates his knowledge of multiple cultural spheres. An interpretative strategy based on a working knowledge of several ethnic spheres allows readers to compare, contrast, and identify sites where black and Asian American cultures come together in both conflict and consensus.

Gunga Din Highway demands this cross-cultural work. The novel weaves a loose narrative thread through a collection of stories, narrative voices and references to fiction, newspaper articles and films. The novel begins not with its chief protagonist, Ulysses S. Kwan, but with his father, Longman Kwan, an actor who specializes in stereotypical roles. Longman goes to Hawaii to convince Anlauf Lorane, the last white man to portray Charlie Chan in cinema, to make an appearance at a music festival. Their encounter reveals Longman's desires to assimilate into American culture, for he dreams of being tapped as the first Chinese American to portray Charlie Chan.

The novel then abruptly switches to Ulysses' recollection of his early childhood. As a youngster he meets Benedict Han and Diego Chang, two other Chinese American boys who become the closest thing to life-long friends that Ulysses will have. The novel alternatively traces the adventures of these friends. Ulysses' path seems the most convoluted: attending Berkeley, working on the railroad, covering a riot in a black neighborhood, participating in the Chinese version of the Black Panthers, and writing Chinese American activist theatre. When he becomes disillusioned with the state of Chinese American drama, he gives up on cultural reform and becomes a writer of zombie movies for Hollywood.

The centrality of several male characters reveals the tension between traditional notions of masculinity and the limited masculinity conferred on Asian American men by American society. Traditional masculinity defines men as strong, dominant, coura- 


\section{Ethnic Studies Review Volume 26: 1}

geous and brave individuals. Richard Majors and Janet Billson assert in Cool Pose: The Dilemma of Black Manhood in America that "being a male means to be responsible and a good provider for self and family," ${ }^{5}$ while Courtland Lee in Black Male Development implies that traditional masculinity is based on the expectations of white men, who, "from boyhood are socialized by family, school and the dominant culture in general, with a masculine sensibility that is composed of an awareness that power and control are their birthright and that they are the primary means of ensuring personal respect, financial security, and success." 6

Chin acknowledges such normative masculine elements in naming his primary protagonist, Ulysses, the Greek Odysseus, the most famous heroic figure in Western literature, thus demonstrating his awareness of the characteristics that define men in mainstream Western culture. The fame of Ulysses is based on his manly virtues of courage and pride. His quests, the cause of his fame, are feats of masculine prowess. By naming his protagonist Ulysses, Chin seeks to imbue him with these manly characteristics.

Such a strong mode of masculinity contrasts greatly with the weak masculinity the dominant culture actually expects from Asian American men. Unlike Ulysses, Longman Kwan, his actorfather, wholeheartedly embraces a masculinity that stereotypes Asian American men as substandard, weak, and dependent. He gladly accepts roles that portray Asian American men as helpless or inferior. As the "Chinaman Who Dies," Longman Kwan portrays a stock Asian actor in war movies who always ends up dead to elicit a sentimental response from the audience.

It is Longman's desire to portray Charlie Chan that best represents his embrace of a weak Asian American masculinity. Charlie Chan functions as the ultimate metaphor for weak Asian American masculinity because he is an Asian American male character deliberately created to be inferior. If the hallmark of a "real" man is his ability to provide for a family, then it follows that Charlie Chan is not a man. Richard Oehling makes the astute observation that "there is always a romance in the Chan movies, but it never involves either Charlie or his children."7 Chan has sons, but no wife, which is implied in the concept of 


\section{Anderson-Chinatown Black Tigers}

family for traditional masculinity. His asexual stance assures his bachelor status, as Elaine Kim notes, since his approval by the public is based on him "as a non-threatening, non-competitive, asexual ally of the white man." 8 Chan fails to secure personal respect or control that real men possess. In the novel Anlauf Lorane explains that Charlie Chan was designed to provide comic relief to white men. Initially Charlie Chan represented an amalgam of Chang Apana, a famous Chinese gun slinger, and Charlie Chaplin, comic of the silent screen. As such the figure does not incorporate the traditional masculine attributes ascribed to Chang Apana and takes more comic characteristics from Chaplin. Jeffery Paul Chan and his colleagues in Three American Literatures cite a general lack of agency in this image of Asian American masculinity:

The white stereotype of the acceptable and unacceptable Asian is utterly without manhood. . . . At worst, the Asian-American male is contemptible because he is womanly, effeminate, devoid of all the traditionally masculine qualities of originality, daring, physical courage and creativity. ${ }^{9}$

To demonstrate his rejection of this weak Asian American masculinity, Chin negatively characterizes Longman. He comes off as a sycophant with no racial pride or dignity. Even his own son, Ulysses, refuses to be connected with him or follow in his footsteps. While Ulysses' best friends do not seem to mind Longman's quest to be embraced by mainstream culture, Ulysses deplores it.

Chin not only identifies the ways that traditional masculinity bans Asian American men from manhood by conferring a weak masculinity upon them, he also suggests that it bars them from the dominant culture itself. Chin acknowledges the discourse of assimilation represented by the figure of Gunga Din, which appears in the title and metaphorically underscores the entire novel. Rudyard Kipling's poem, "Gunga Din," like most of his work, invites a colonialist reading. In the following passage, the British soldier narrator assumes an imperialist position over the native Gunga Din in describing his character:

If we charged or broke or cut, You could bet your bloomin' nut, 


\section{Ethnic Studies Review Volume 26: 1}

'E'd be waitin' fifty paces right flank rear.

With 'is mussick on 'is back,

'E would skip with our attack,

$\mathrm{An}^{\prime}$ watch us till the bugles made "Retire,"

An'for all 'is dirty 'ide

'E was white, clear white, inside

When 'e went to tend the wounded under fire!

(Kipling, "Gunga Din")

The narrative voice in the poem embodies traditional masculinity that gives him the authority to define Gunga Din. The only thing that makes Gunga Din acceptable is the fact that he is "white, clear white, inside," suggesting that he had assimilated the dominant society's characterization of him as a servant. The narrator praises Gunga Din for his service to the British soldiers, which mirrors the service of the Indian people to the British empire. Gunga Din is a good man, not because of intrinsic characteristics, but because he serves his masters well in a war to promote British imperialism. The western voice of the British soldier confines Indian men, and by extension, all Asian and Asian American men, to the position of servant. B.J. Moore-Gilbert in "Kipling and Orientalism" suggests that Kipling's poem falls into Edward Said's conception of orientalism, which "has as its aim dominating, restructuring, and having authority over the Orient. ... It conceives of the East as radically 'other' and alien to the West."10 Gunga Din only becomes acceptable as a member of the dominant culture if he acquiesces and loses any hint of his masculinity. In this way traditional masculinity becomes linked with cultural membership and is used to bar men of Asian descent from the dominant culture.

Fu Manchu represents another figure of Asian masculinity that underscores the chasm between Western culture and men of Asian descent by reinforcing the foreignness of men of Asian descent. Elaine Kim describes the Asian villain as an individual "who has mastered Western knowledge and science without comprehending Western compassion and ethics. . . . Fu Manchu is the diametrical opposite of the white hero: he is, in [Sax] Rohmer's words, 'not a normal man. ... [he is] unbound by the laws of men."11 Fu Manchu emphasizes the alien nature of Asian 
men. Because he does not embrace Western values and chooses to pursue depravity, he is barred from mainstream culture. So are men who look like him.

Chin revises the Fu Manchu and in doing so rejects the assumption that Asian American men are not part of American culture. As an Asian American artist, Ulysses consciously refuses to portray Fu Manchu as a perpetual alien. Instead, he chooses to depict the figure to reflect " a Chinese American culture that kicks white racism in the balls with a shit-eating grin" (261). His use of the figure is a form of satire "where you make fun of how they think and what they say in order to make them look stupid" (257). Such strategies are necessary to counteract the distance that such figures create between Asian American men and the dominant culture.

While Chin finds little to emulate in the images of Asian American men perpetuated by the general culture, he is drawn to African American culture for models of ethnic masculinity. Both African American and Asian American men have similar experiences at the hands of the dominant culture. Historically, black men have been typecast as sexual threats to white women and the moral inferiors to white men. Jacqueline Jones notes in her study of black families that any potential sexual advance on the part of black men "provided white men as a group with an opportunity to reaffirm their own sense of racial superiority and 'manhood,'" resulting in the "mutilation and castration of lynching victims (invariably accused of raping white women) [which] brought into explicit focus the tangle of 'hate and guilt and sex and fear' that enmeshed all southerners well into the twentieth century." 12 Chinese immigrant men embodied a similar danger to white racial purity, which was reflected in anti-marriage laws of the 19th century. Historian Sucheng Chan argues that "elaborate 'scientific' explanations of nonwhite 'inferiority'. . . provided an ideological justification for treating not only Asians, but other people of color, in a discriminatory and exploitative manner. To preserve Anglo-Saxon purity, it was argued, no interracial mixing should be allowed"; 13 thus, men of both ethnic groups have similar motivations to define their own masculinities.

Regarding ethnic masculinity, Chin's work resonates specifically with the ideas of African American writer Ishmael Reed. 


\section{Ethnic Studies Review Volume 26: 1}

The author of several novels and works of non-fiction, Reed has gained a reputation for being outspoken. From his 1960s novel, The Freelance Pallbearers, to his 1990s novel, Japanese By Spring, Reed demonstrates his penchant for critiquing the status quo. Discrimination, the black middle class, and academia are only a few of his targets. These subjects also recur in his nonfiction, which bear titles like Writing is Fighting: Thirty Years of Boxing on Paper. His aggressive tone and caustic style are designed to provoke and challenge accepted ideas.

Chin's usage of Reed's approach to ethnic masculinity is not unusual, given that they share a professional and creative relationship. ${ }^{14}$ In 1974 Reed stated in an interview that when editing a special issue on Asian American writing for the Yardbird Reader, his literary journal, he not only worked with Chin but also recommended him to readers who wanted a "true" multicultural account. 15 In one of his frequent tirades against the American literary establishment, Reed observes that "another group neglected by the American Writing Establishment [is] the Asian-Americans, descendents of the Chinese who came to the West to build railroads." He goes on to call Chin by name and reveal his distinction of having written the first play by a Chinese American produced in a New York theater. ${ }^{16}$ In the foreword to the Literary Mosaic Series that features Asian American literature, Reed identifies Chin as one of "the four horsemen of Asian American literature" for his fiction and nonfiction contributions to the field. Reed also occupies a prominent place on Chin's cultural radar screen, as evidenced by the dedication in Chin's most recent essay collection, Bulletproof Buddhists: "To Ishmael Reed: Writing is Fighting."

In addition to professional admiration, Chin's writing mirrors Reed's aggressive rhetoric, which identifies the dominant society as the enemy that must be defeated. In describing his writing, Reed meditates on characterizations of himself as a boxer:

I don't mince my words. Nor do I pull any punches, and though I've delivered some low blows over the years, I'm becoming more accurate, and my punches are regularly landing above the waistline. . . . A black boxer's career is the perfect metaphor for the career of a black male. Every day is like being in the gym, spar- 
ring with impersonal opponents as one faces the rudeness and hostility that a black male must confront in the United States, where is he is the object of both fear and fascination. ${ }^{17}$

Reed asserts that he engages in combat with the dominant culture. The culture engages in racial slights that black men receive. Significantly this metaphor of boxing empowers the black male who may feel a lack of agency as an object and allows him to fight back. Reed's pugilistic rhetoric represents an affirmative response to his opponent that attempts to exclude black men from manhood.

Similarly, Chin indicts the dominant society as an adversary. He captures this aggressive rhetoric in his essay, "Confessions of a Chinatown Cowboy":

White America is as securely indifferent about us as men, as Plantation owners were about their loyal house niggers. House niggers is what America has made of us, admiring us for being patient, submissive, esthetic, passive, accommodating essentially feminine in character. . . . what whites call 'Confuciusist,' dreaming us up a goofy version of Chinese culture to preserve in becoming the white male's dream minority. ${ }^{18}$ Chin's rhetoric bears the imprint of Reed with its aggressive style. His words resemble punches as he accuses "white America" of making Asian American men "niggers." He complains about the passivity conferred on Asian American men, which robs them of masculinity. Because the dominant society has the power to define, it is ultimately at fault in the emasculation of Asian American men. Like Reed, Chin aggressively confronts mainstream America and by his very strong words, reclaims agency and control for Asian American men.

In addition to identifying the enemy, Chin's work also mirrors Reed's assertion of agency based on ethnic men's own terms. In Reed's novel, Japanese by Spring (1993), Benjamin "Chappie" Puttbutt, the protagonist, is initially conservative, but when he is denied tenure and through a fluke subsequently placed as the right hand of the new president of the college, he exercises the agency his new position affords him. When confronting the English professor who argued against his tenure, Chappie notes 


\section{Ethnic Studies Review Volume 26: 1}

that "he was sounding like his father. Accepting his father's vision of the world. As a battleground between the strong and the weak."19 After rebuffing the chair of the Women's Studies Department, Chappie asserts: "Life is war. And on this campus, he was second in command." 20 Chappie exhibits agency in retaliation to those who exploited him because of his race. He exudes strength against a racialized enemy. His new position of power gives him the wherewithal to assert himself as a black man to those who previously denied him power.

While such strength and agency are hallmarks of traditional masculinity, they can become hallmarks of black masculinity when they function against racial discrimination and perceived disrespect. Marginalized from conventional masculinity by racism, Clyde Franklin suggests black men may "develop measures of masculinity based on other traits such as physical strength, aggressiveness, dominance, sexual conquest, conspicuous consumption and exterior emotionless." 21 Majors and Billson describe a set of behaviors exhibited by black men as the "cool pose," "a potpourri of violence, toughness and symbolic control over others." 22 Defiance and a condescending attitude towards anything that does not acknowledge the status of the black man represent an aggressive form of black masculinity. Chappie's responses to the English professor and Women's Studies chair exude a sense of symbolic control.

Chin's Ulysses also enacts this defiant attitude as a response to what he perceives as disrespect. In Chinese after-school, Ben Han describes Ulysses' challenge to their teacher:

None of us had ever heard Ulysses or anyone talk back

to a teacher like this. The only way I could describe

Ulysses at the time was to say he talked to the Horse [Mr. Mah] as if he were the boss. Every day they argued. ... Ulysses never gave an inch, never stopped fighting once he started" (92).

Rather than "staying in his place, Ulysses defies Mr. Mah as a figure of authority. He talks back, exhibiting the same symbolic control, dominance and aggressiveness found in Reed's black masculinity.

Such defiance derived from black masculinity is particularly attractive for Asian American men, who risk being subsumed 
by the model minority stereotype, which Jinqi Ling notes is "a term that distinguished Asian Americans from blacks, Hispanics, and Native Americans during the political ferment of the 1960s because the latter's back-talking militancy is typically viewed as a sign of male potency." 23 Because this stereotype paints men of Asian descent as passive and docile, Chin expresses a sense of admiration for the boldness of black masculinity:

And there we Chinaman were, in Lincoln Elementary School, Oakland, California, in a world where manliness counts for everything, surrounded by bad blacks. . . who were still into writing their names into their skin with nails dipped in ink. They had a walk, a way of wearing their pants on the brink of disaster, a tongue, a kingdom of manly style everyone respected." 24 Chin later asserts that "the going image of Chinese manhood wasn't swordsman. It was a sissy servant, Charlie Chan." 25 To compensate, Asian American men may exhibit the rhetorical aggressiveness of black masculinity to offset the emasculating effects of the feminine stereotype of the model minority.

Chin takes his cultural project one step further by blending this aggressive form of black masculinity with aspects of Chinese heroism. This aggressive masculinity complements the heroic tradition in Chinese culture because both are in part based on strength and agency for ethnic men. The cultural privilege given to men by the Chinese heroic tradition breeds feelings of dominance. As with black masculinity, this promotes the values of extreme individualism, alienation, and aloofness. The result is a tough Asian man, and like his tough black brother, Chin argues, that "true" Chinese heritage is marked, not by submissiveness but by a warrior tradition:

All of us-men and women-are born soldiers. The soldier is the universal individual. . . L Life is war. The war is to maintain personal integrity in a world that demands betrayal and corruption. All behavior is strategy and tactics. All relationships are martial. ${ }^{26}$

As a result Ulysses' challenge to Mr. Mah discussed earlier also can be read as an example of Chinese heroism, for his behavior hearkens back to Chinese heroes. The argument is sparked by Mr. Mah's implication that Ulysses has nothing use- 


\section{Ethnic Studies Review Volume 26: 1}

ful to say; he tries to silence him. Earlier, Ulysses and his friends declared themselves Brothers of the Oath of the Peach Garden, alluding to the Romance of the Three Kingdoms, where Lowe Bay, Kwan Yu and Chang Fay "swear to serve China and save the people" (73). Chin elaborates in an essay that Kwan Yu, the brother Ulysses emulates in the novel, "is the exemplar of the universal man, a physically and morally self-sufficient soldier who is a pure ethic of private revenge." 27 When Ulysses asserts his independence to Mr. Mah, he enacts Kwan Yu's self-sufficiency. Just as those heroes fight for China, Ulysses fights in Mr. Mah's classroom and demonstrates a form of Chinese heroism, for just as they fought for the honor of China, so too Ulysses 'fights' for his own Chinese American identity in Mr. Mah's classroom.

While the characters cannot pick up swords and start a war against those they perceive as their enemies, they can use language to enact their Chinese heroism. In his encounter with Mr. Mah, Ulysses uses language to create his own reality and wrestle control from those who exercise power over him. This can be seen when Ulysses later challenges Ben Han's girlfriend about the 'true' Chinese tradition:

The fact is that Chinese literature-The Three Brothers of the Oath of the Peach Garden, Sam Gawk Yurn Yee, The Romance of the Three Kingdoms, Fung Sun Bong and Kwang Kung-has nothing to do with your fiancée's strange tales. The stories she says are Chinese aren't and never were. She's not rewriting Chinese anything, man. She's just doing a rewrite of Pearl Buck and Charlie Chan and Fu Manchu. . . . This isn't Chinese. This isn't the Three Brothers. This isn't Kwan Yin. How does she get away with this bullshit? $(261,275)$

Ulysses is upset because he knows the power of language. By butchering the stories, Ben's girlfriend compromises Chinese culture and its value for Chinese Americans. Ulysses counters by referring to 'true' Chinese literature made up heroic sagas and daring acts of bravery. He advocates retaining the battles and courageous deeds of the heroes. These attributes, Cheung asserts, "show further that Chinese. . . have a heroic-which is to say militant-heritage." 28 By doing so, he himself acts heroically 
to save Chinese culture, just like the Three Brothers of the Oath of the Peach Garden.

Furthermore, Chin and his colleagues highlight the relationship between language and an Asian American masculinity that incorporates elements of Chinese heroism:

Language is the medium of culture and the people's sensibility, including the style of manhood. Language coheres the people into a community by organizing and codifying the symbols of the people's common experience. Stunt the tongue and you have lopped off the culture and sensibility. On the simplest level, a man in any culture speaks for himself. Without a language of his own, he is no longer a man. ${ }^{29}$

The quest to use language to describe Asian American cultural expression becomes the measure of a man. The articulation of cultural expression recaptures masculinity taken away through language by the dominant culture. Language holds the power of the Asian American community, and without it, Asian American men are not men. Chin and his colleagues view language as a weapon they can use to articulate their experiences as Asian American men.

As Asian American men, they also recognize the negative ramifications of language for their masculinity. Language in this sense refers not only to a general means of communication but also to English specifically as a linguistic system which excludes Asian American men. In the eyes of Chin and his colleagues language becomes a weapon wielded against them, a two-edged sword that may put them at a disadvantage in their quest to enact a masculinity based on heroism:

Minority writers, specifically Asian American writers, are made to feel morally obliged to write in a language produced by an alien and hostile sensibility. . . . Only Asian Americans are driven out of their tongues and expected to be at home in a language they never use and a culture they encounter only in books written in English. This piracy of our native tongues by white culture amounts to the eradication of a recognizable Asian American culture here. ${ }^{30}$

Language functions as a tool against Asian American men to 


\section{Ethnic Studies Review Volume 26: 1}

force them into a homogenous cultural discourse that silences them as ethnic men. This use of language is wholly imperial and oppressive, presumably providing nothing of value culturally for the minority writer. It is also less of an issue for the African American writer, who is more at home because s/he speaks the same language. Chin and his coauthors also link language and the dominant culture that produces it, indicting both for their imperialism toward Asian American men.

While Chin's conflation of black masculinity and Chinese heroism results in a complex response to emasculation of Asian American men by the dominant culture, it fails to offer alternative definitions of masculinity outside the aggressive vein. Elaine Kim in Asian American Literature observes that "Chin flails out at the emasculating aspects of oppression, but he accepts his oppressor's definition of masculinity." 31 So does Ulysses, for within the confines of the novel he does not challenge the dominance that defines masculinity nor does he explore alternative masculinities such as the scholar, the teacher, and the humanitarian.32 A more flexible form of heroism would create a more comprehensive discourse on masculinity rather than just one that confronts emasculating forces. King-kok Cheung in his study of Chinese masculinity points to the Chinese male image of the sushen, or poet-scholar, as a Chinese alternative to masculinity:

The poet-scholar, far from either brutish or asexual, is seductive because of his gentle demeanor, his wit and his refined sensibility. He prides himself on being indifferent to wealth and political power and seeks women and men who are his equals in intelligence and integrity. ... . Surely reclaiming the ideal of the poet-scholar will combat [the] cultural invisibility [of Asian American men].

Chin's conflation of masculinities also dissociates Ulysses from the very black masculinity that informs his identity. During his formative years, Ulysses feels distanced from African Americans. While covering a riot in a black neighborhood, Ulysses thinks about his estrangement:

I don't know this ghetto. This ghetto doesn't know me. ... I'm a Chinaman. Why am I trying to feel like I've been here before? Everywhere outside of the Mother 


\section{Anderson-Chinatown Black Tigers}

Lode country I have been a stranger all my life. . . . 'Home,' the way the Negro dishwasher standing at a urinal talks about 'home' in New Orleans, is not the Oakland ghetto or Chinatown" (142).

Given that his character takes so much from black masculinity to form his identity, this seems curious. Despite Chin's assertions in his essays that the plight of African American and Chinese American men are similar, he directs his protagonist to question any attempt to draw parallels between the experiences of the two groups of ethnic men. To a certain extent, Chin describes Ulysses' alienation in the black neighborhood as equal to the alienation he feels as a Chinese American in the dominant culture. Since Chin has already declared the dominant society the enemy, he implies a similar characterization for the African American community as well.

Chin in addition uses Ulysses to characterize the Black Panthers' brand of heroism as superficial. Ulysses recalls his involvement in the Chinatown Black Tigers, an Asian American activist organization loosely based on the Black Panthers. In doing so, he emphasizes the outer trappings of black masculinity over the oppression of the dominant culture by parodying the silver shades, the mustache and the black revolutionary turtleneck as superficial elements of the movement. Ulysses reduces the movement to a catchy slogan. Such depictions are reductive, for as Robin D.G. Kelley suggests, the Black Panther Party were also viewed as models for positive change despite their flaws. Part of the revolutionary stance of street gangs can be traced to the roots of the Black Panther Party and to members like "Brother Crook (aka Ron Wilkins) [who] founded the Community Alert Patrol to challenge police brutality in the late 1960s." 34 Chin does not address the very conflicted legacy of the Black Panther Party, but only picks on it flaws. How bad can they be if they espoused many of the principles he does in his defensive posture against The Man?

While this seems contradictory, Chin's final move may represent yet another lesson gleaned from Reed: the paramount value of the individual vision. Sharon Jessee recalls that "Reed has a well-documented antipathy for any kind of strict regimen of objectives," choosing instead to "advocate that every individ- 


\section{Ethnic Studies Review Volume 26: 1}

ual create his own aesthetic for himself." 35 Similarly, Chin champions ultimate authority for the individual. In the novel Ulysses takes a giant step away from communalism when he quits activist theatre, declaring, "no more doing it for the people. No more organized poetry" (346). Ulysses goes from directing Chinese American activist theater to writing Hollywood zombie movies: "If The Night of the Living Third World Dead brings in just $\$ 30$ million, I can quit writing for the Four Horsemen [Hollywood executives] and be rich enough to be forgotten" (345-346). Ulysses embraces the self-serving art of commercial writing. He wants to make enough money to be able to make his own brand of art without any responsibilities to an audience. Because Ulysses is "pure self-invention," he is free from cultural obligations and expectations, including those imposed even by Chinese American culture. By choosing to produce zombie movies, Ulysses does not have to engage racial issues at all.

This shift towards individualism diverges from the communalism advocated by many Chinese American critics. A concept like Asian American panethnicity underscores communalism: Yen Le Espiritu sees within it large-scale identities, concerted action against dominant groups, and challenges to the allocation of power in society where all benefit under the Asian American umbrella. ${ }^{36}$ Conversely, Chin sees individuality as a strategy to combat racism and discrimination. Such individuality also appears to disavow complete allegiance to any ideology, including that of African American masculinity.

Frank Chin's unconventional defense of Asian American masculinity may act as a lightning rod for a wide range of scholars and critics, but it also affords a unique opportunity to witness interethnic dynamics at work. Chin embeds some of Reed's key elements regarding ethnic masculinity in his novel and writings, adapts others to complement Chinese heroism, and rejects still others. In doing so he provides a complex response to the emasculating figures promoted by the dominant culture.

\section{WORKS CITED}

Chan, Jeffery Paul, Frank Chin, Lawson Fusao Inada and Shawn Wong. "An Introduction to Chinese American and Japanese American Literatures." In Three American Literatures, edited by Houston Baker, 197-226. New York: MLA, 1982. 


\section{Anderson-Chinatown Black Tigers}

Chan, Sucheng. Asian Americans: An Interpretative History. New York: Twayne Publishers, 1991.

Cheung, King-Kok. "Of Men and Men: Reconstructing Chinese American Masculinity." In Other Sisterhoods: Literary Theory and U.S. Women of Color, edited by Sandra Kumamoto Stanley, 173-199. Urbana: University of Illinois Press, 1998.

-----. "The Warrior Woman versus The Chinaman Pacific: Must a Chinese American Critic Choose Between Feminism and Heroism?" In Conflicts in Feminism, edited by Marianne Hirsch and Evelyn Fox Keller, 234-251. New York: Routledge, 1990.

Chin, Frank. "Come All Ye Asian American Writers of the Real and the Fake." In The Big Aiiieeeee!: An Anthology of Chinese American and Japanese American Literature, edited by Jeffery Paul Chan, Frank Chin, Lawson Fusao Inada and Shawn Wong, 1-93. New York: Meridian, 1991.

----.."Confessions of a Chinatown Cowboy." Bulletin of Concerned Asian Scholars 4 (1972): 58-70.

-----. Gunga Din Highway. Minneapolis: Coffee House Press, 1994.

Espiritu, Yen Le. Asian American Panethnicity: Bridging Institutions and Identities. Philadelphia: Temple University Press, 1992.

Franklin, Clyde. The Changing Definition of Masculinity. New York: Plenum Press, 1984.

Grobman, Laurie. "Towards a Multicultural Pedagogy: Literary and Nonliterary Traditions." MELUS 26.1 (2001): 221-240.

Harris, lan. Messages Men Hear: Constructing Masculinities. Bristol: Taylor \& Francis, 1995.

Jessee, Sharon. "Ishmael Reed's Multi-Culture: The Production of Cultural Perspective." MELUS 13.3/4 (1986): 5-14.

Jones, Jacqueline. Labor of Love, Labor of Sorrow: Black Women, Work, and the Family From Slavery to the Present. New York: Vintage, 1985.

Kelley, Robin D.G. Race Rebels: Culture, Politics and the Black Working Class. New York: The Free Press, 1994.

Kim, Elaine. Asian American Literature: An Introduction to the 


\section{Ethnic Studies Review Volume 26: 1}

Writings and Their Social Context. Philadelphia: Temple University Press, 1982.

Lee, Courtland. "Black Male Development: Counseling the 'Native Son.'" In Problem Solving Strategies and Interventions for Men in Conflict, edited by Dwight Moore and Fred Leafgren. Alexandria: American Association for Counseling and Development, 1990.

Ling, Jinqi. "Identify Crisis and Gender Politics: Reapproriating Asian American Masculinity." In An Interethnic Companion to Asian American Literature, edited by King-Kok Cheung, New York: Cambridge University Press, 1997. 312-337.

Majors, Richard and Janet Billson. Cool Pose: The Dilemma of Black Manhood in America. New York: Maxwell Macmillan International, 1992.

Moore-Gilbert, B.J. Kipling and "Orientalism." New York: St. Martin's Press, 1986.

Neal, Larry. "The Black Arts Movement." In Within the Circle: An Anthology of African American Literary Criticism from the Harlem Renaissance to the Present, edited by Angelyn Mitchell, 184-198s. Durham: Duke University Press, 1994.

Newfield, Christopher and Avery F. Gordon. "Multiculturalism's Unfinished Business." In Mapping Multiculturalism, edited by Christopher Newfield and Avery F. Gordon, 76-115. Minneapolis: University of Minnesota Press, 1996.

Oehling, Richard. "The Yellow Menace: Asian Images in American Film." In The Kaleidoscope Lens: How Hollywood Views Ethnic Groups, edited by Randall M. Miller. USA: Jerome S. Ozer, 1980. $182-206$.

Reed, Ishmael. "Boxing on Paper: Thirty-Seven Years Later." In Writin' Is Fightin': Thirty-Seven Years of Boxing on Paper. New York: Atheneum, 1990.

-----. "Ishmael Reed-Self Interview." In Shrovetide in Old New Orleans. Garden City: Doubleday and Company, 1978.

-----. Japanese by Spring. New York: Penguin, 1993.

-----. "The Multi-Cultural Artist: A New Phase in American Writing." In Shrovetide in Old New Orleans. Garden City: Doubleday and Company, 1978. 
Anderson-Chinatown Black Tigers

Wong, Sau-ling Cynthia. "Chinese American Literature." In An Interethnic Companion to Asian American Literature, edited by KingKok Cheung, 39-61. New York: Cambridge University Press, 1997.

\section{NOTES}

1 Chin, Gunga Din Highway. All pages.

2 Wong, 48

3 Newfield, 79

${ }^{4}$ Grobman, 236

5 Majors, 30

6 Lee, 126

7 Oehling, 197

$8 \mathrm{Kim}, .18$

9 Chan, 211

10 Moore-Gilbert, 1-3

11 Kim, 8

12 Jones, 149

12 Chan, 54

14 Discussion

15 Reed, "Interview", 248

16 Reed, "Multicultural", 254

17 Reed, "Boxing", 6

18 Chin, "Confessions", 67

19 Reed, "Japanese", 98

20 Reed, "Japanese", 110

21 Franklin, 58-59 
Ethnic Studies Review Volume 26: 1

22 Majors, 33

23 Ling, 315

24 Chin, "Confessions", 64

25 Chin, "Confessions", 64

26 Chin, "Come All", 39

27 Chin, "Come All", 39

28 Cheung, "Warrior", 241-2

29 Chen, 226

30 Chen, 271-2

31 Kim, 90

32 Harris

33 Cheung, "OF Men", 190 